\title{
Hubungan Awitan Pubertas dan Status Sosial Ekonomi serta Status Gizi padla Anak Perempuan
}

\author{
Woro Indaryani, Rudy Susanto, JC Susanto \\ Bagian Ilmu Kesehatan Anak FK Universitas Diponegoro RSUP. Dr. Kariadi Semarang
}

\begin{abstract}
Latar belakang. Usia awitan pubertas dapat dipakai untuk menentukan apakah seorang anak perempuan mengalami pubertas dini atau terlambat. Di Indonesia, masih terdapat perbedaan status sosial ekonomi dan status gizi antara daerah pedesaan dan perkotaan, yang berpengaruh terhadap awitan pubertas di kedua daerah.

Tujuan. Mengetahui hubungan antara rerata usia awitan pubertas dengan status sosial ekonomi dan status gizi pada anak perempuan di daerah pedesaan dan perkotaan

Metode. Penelitian cross sectional dilakukan antara Mei-September 2009 terhadap 502 anak perempuan, siswa 5 Sekolah Dasar Getasan (pedesaan), 5 Sekolah Dasar Gajahmungkur (perkotaan) yang berumur 8-13 tahun. Subjek penelitian dipilih secara stratified random sampling. Awitan pubertas ditentukan berdasarkan pertumbuhan payudara atau rambut pubis, sesuai Tanner-2. Status ekonomi dinilai berdasarkan kriteria Sajogyo. Status gizi berdasarkan indeks massa tubuh (WHO, 2005). Analisis menggunakan uji t-tidak berpasangan dan uji korelasi Spearman.

Hasil. Awitan pubertas secara bermakna lebih awal di perkotaan (124 \pm 10$)$ bulan dibandingkan di pedesaan $(131 \pm 11)$ bulan. Awitan pubertas terjadi lebih awal pada kelompok sosial ekonomi tinggi dan kelompok indeks massa tubuh tinggi $(p<0,001)$.

Kesimpulan. Anak perempuan di perkotaan mengalami pubertas lebih awal dibandingkan di pedesaan. Terdapat hubungan bermakna antara status ekonomi dan status gizi dengan awitan pubertas. (Sari Pediatri 2010;11(5):374-8).
\end{abstract}

Kata kunci: awitan pubertas, anak perempuan, perkotaan, pedesaan

$\mathrm{P}$ ubertas adalah masa transisi dari masa anak ke masa dewasa, ditandai dengan munculnya tanda-tanda seksual sekunder dan kemampuan bereproduksi. Pubertas terjadi sebagai akibat dari peningkatan sekresi gonadotropin releasing hormone

\section{Alamat korespondensi:}

Dr. Rudy Susanto, SpA(K). Lab. IKA FK-UNDIP/RS Dr. Kariadi Semarang Jawa Tengah. Telp. +6224-8311471, 8414296, Fax. +6224$8414296,8318617$.
(GnRH) dari hipotalamus dan diikuti oleh sekuen perubahan sistem endokrin yang komplek serta timbulnya sistem umpan balik negatif dan positif. Sekuen ini akan diikuti oleh tanda seks sekunder, pacu tumbuh, dan kesiapan untuk bereproduksi. ${ }^{1-3} \mathrm{Di}$ negara berkembang masih didapatkan kecenderungan penurunan usia awitan pubertas, yang mungkin disebabkan oleh perubahan standar kehidupan. Selain itu masih terdapat perbedaan status sosial ekonomi dan gaya hidup di pedesaan dan perkotaan, sehingga menyebabkan terjadinya perbedaan usia awitan 
pubertas. Status sosial ekonomi keluarga mempengaruhi status gizi anak, dan anak dengan status gizi baik akan mengalami pubertas lebih awal..$^{2-4}$

Tujuan penelitian untuk mengetahui hubungan antara rerata usia awitan pubertas dengan status sosial ekonomi dan status gizi pada anak perempuan di daerah perkotaan dan pedesaan.

\section{Metode}

Penelitian cross sectional telah dilakukan terhadap 502 siswa perempuan Sekolah Dasar kelas III-VI di Kecamatan Gajah Mungkur, Kotamadya Semarang (perkotaan) dan Kecamatan Getasan, Kabupaten Semarang (pedesaan) pada bulan Mei - September 2009. Daerah pedesaan dan perkotaan dipilih berdasarkan Potensi Desa Sensus Ekonomi (PODES SE) 2008 Badan Pusat Statistik Jawa Tengah dengan metode purposive sampling. Penentuan kelima sekolah dasar di setiap kecamatan secara random sederhana. Siswa yang memenuhi kriteria inklusi dari masingmasing sekolah dipilih secara stratified random sampling sampai didapatkan jumlah 251 siswa dari masing-masing daerah. ${ }^{5,6}$ Kriteria inklusi adalah siswa perempuan berumur 8-13 tahun dan bersedia diikutsertakan dalam penelitian. Kriteria eksklusi apabila siswa diketahui menderita penyakit kronik/ berat dan sedang mendapat pengobatan hormonal.

Pengumpulan data dimulai dengan mencatat data umum subjek. Usia pubertas dihitung dalam bulan. Tinggi badan diukur dengan alat stature meter $\mathrm{SH}-$ $2^{\circ}$ dengan ketelitian $0,1 \mathrm{~cm}$, sedangkan berat badan ditimbang dengan timbangan Beurer BG 20, ketelitian $0,1 \mathrm{~kg}$. Status gizi berdasarkan kurva indeks massa tubuh (IMT), menurut kriteria WHO 2005. Awitan pubertas ditentukan berdasarkan tingkat perkembangan payudara dan rambut pubis, sesuai dengan Tanner 2. Status sosial ekonomi dibedakan menjadi 6 kelompok pendapatan, yang ditentukan berdasarkan pendapatan rumah tangga/ tahun yang ekuivalen dengan nilai jual beras berdasarkan kriteria Sajogyo ${ }^{7-9}$

\section{Hasil}

Penelitian dilakukan di lima sekolah dasar Negeri di Kecamatan Getasan Kabupaten Semarang dan lima sekolah dasar Negeri di Kecamatan Gajahmungkur Kotamadya Semarang. Jumlah siswa perempuan yang

Tabel 1. Karakteristik subjek $(\mathrm{n}=502)$

\begin{tabular}{|c|c|c|c|}
\hline \multirow[t]{2}{*}{ Karakteristik } & Pedesaan $n=251$ & Perkotaan $\mathrm{n}=251$ & \multirow[t]{2}{*}{$\mathrm{p}$} \\
\hline & $\mathrm{n}(\%)$ & $\mathrm{n}(\%)$ & \\
\hline \multicolumn{4}{|l|}{ Sekolah dasar kelas } \\
\hline 3 & $60(23,9)$ & $46(18,3)$ & \\
\hline 4 & $60(23,9)$ & $68(27,1)$ & \\
\hline 5 & $76(30,3)$ & $73(29,1)$ & \\
\hline 6 & $55(21,9)$ & $64(25,5)$ & $0,3^{*}$ \\
\hline \multicolumn{4}{|l|}{ Status gizi } \\
\hline - Kurang (IMT< p 5) & $47(18,7)$ & $17(6,8)$ & \\
\hline - Baik (IMT p 5-84) & $189(75,3)$ & $192(76,5)$ & \\
\hline - Risiko overweight (IMT p 85-95) & $10(4,0)$ & $18(7,2)$ & \\
\hline - Overweight ( IMT>p 95) & $5(2,0)$ & $24(9,6)$ & $<0,001^{*}$ \\
\hline \multicolumn{4}{|l|}{ Status ekonomi (Sajogyo) } \\
\hline - Peringkat 1 & $31(12,4)$ & $121(48,2)$ & \\
\hline - Peringkat 2 & $82(32,7)$ & $85(33,9)$ & \\
\hline - Peringkat 3 & $45(32,7)$ & $27(10,8)$ & \\
\hline - Peringkat 4 & $75(29,9)$ & $17(6,8)$ & \\
\hline - Peringkat 5 & $12(4,8)$ & $1(0,4)$ & \\
\hline - Peringkat 6 & $6(2,4)$ & $0(0,0)$ & $<0,001^{* *}$ \\
\hline
\end{tabular}

Sari Pediatri, Vol. 11, No. 5, Februari 2010 
berusia 8 sampai 13 tahun 512 orang. Sepuluh siswa tidak masuk sekolah saat penelitian dilakukan dan dua siswa tidak memenuhi kriteria inklusi karena sedang dalam pengobatan tuberkulosis paru.

Karakteristik subjek penelitian di kedua daerah tertera pada Tabel 1.

Subjek penelitian di kedua daerah sebagian besar adalah kelas lima SD, sedangkan yang paling sedikit di pedesaan adalah kelas enam dan di perkotaan adalah kelas tiga, tetapi perbedaan ini tidak bermakna secara statistik $(\mathrm{p}=0,3)$. Terdapat perbedaan bermakna status gizi dan status ekonomi antara subjek di daerah pedesaan dan perkotaan $(p<0,001)$. (Gambar 1)

Pubertas ditandai dengan pemeriksaan Tanner-2 di perkotaan didapatkan 91 siswa, sedangkan di pedesaan 72 siswa. Selanjutnya yang dianalisis adalah subjek dengan tingkat pubertas menurut Tanner-2, dengan karakteristik tertera pada Tabel 2.

Tabel 2 menunjukkan overweight lebih banyak dijumpai di perkotaan dan tidak didapatkan di pedesaan. Terdapat perbedaan yang bermakna pada

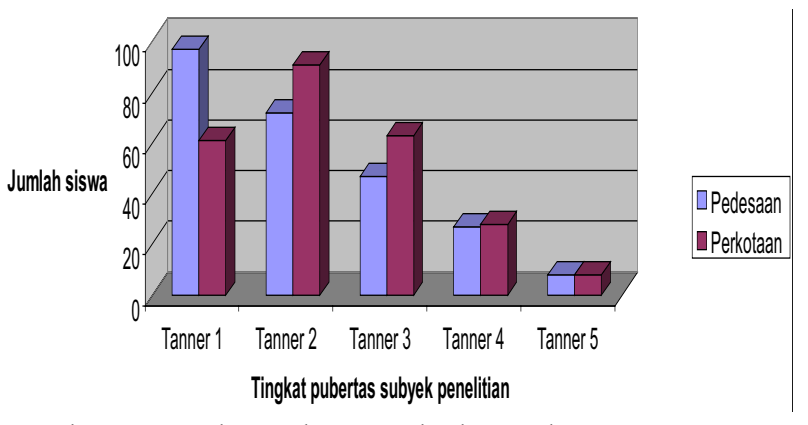

Gambar 1. Tingkat pubertas subjek penelitian

status ekonomi subjek penelitian di pedesaan dan perkotaan. Subjek penelitian dengan status ekonomi peringkat satu lebih banyak dijumpai di perkotaan, sedangkan di pedesaan sebagian besar adalah peringkat dua dan empat.

Subjek penelitian di perkotaan mempunyai usia awitan pubertas lebih awal (124士10) bulan dibanding-

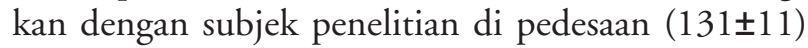
bulan $p<0,001$. Hubungan antara umur subjek

Tabel 2. Karakteristik subjek dengan tingkat pubertas Tanner-2

\begin{tabular}{lccc}
\hline Karakteristik & $\begin{array}{c}\text { Pedesaan } \\
\mathrm{n}=91\end{array}$ & $\begin{array}{c}\text { Perkotaan } \\
\mathrm{n}=72\end{array}$ & $\mathrm{p}$ \\
\hline Status gizi (n, \%) & $6(8,3)$ & $7(7,7)$ & \\
Gizi kurang (IMT<p 5) & $65(90,3)$ & $72(79,1)$ & \\
Gizi baik (IMT p 5-84) & $1(1,4)$ & $6(6,6)$ & \\
Risiko overweight (IMT p 85-95) & $0(0,0)$ & $6(6,6)$ & $0,6^{*}$ \\
Overweight (IMT>p 95) & & & \\
Sosial ekonomi (n, \%) & $12(16,7)$ & $41(45,1)$ & \\
Peringkat 1 & $18(25,0)$ & $32(35,2)$ & \\
Peringkat 2 & $17(23,6)$ & $10(11,0)$ & \\
Peringkat 3 & $18(25,0)$ & $7(7,7)$ & \\
Peringkat 4 & $5(6,9)$ & $1(1,1)$ & \\
Peringkat 5 & $2(2,8)$ & $0(0,0)$ & $<0,001^{*}$ \\
Peringkat 6 & & & \\
\hline
\end{tabular}

*Uji Kolmogorov Smirnov

Tabel 3. Perbedaan usia awitan pubertas subjek di perkotaan dan pedesaan

\begin{tabular}{cccc}
\hline \multirow{2}{*}{ Usia awitan pubertas } & \multicolumn{2}{c}{ Kategori tempat tinggal } & p \\
\cline { 2 - 3 } & $\begin{array}{c}\text { Pedesaan } \\
\text { Rerata } \pm \text { SD }\end{array}$ & $\begin{array}{c}\text { Perkotaan } \\
\text { Rerata } \pm \text { SD }\end{array}$ & $<0,001^{*}$ \\
\hline $\begin{array}{c}\text { Rerata usia awitan } \\
\text { pubertas (bulan) }\end{array}$ & $131 \pm 11$ & $124 \pm 10$ & \\
\hline
\end{tabular}

* uji t tidak berpasangan 
penelitian dengan status sosial ekonomi dan status gizi yang dinilai dengan indeks masa tubuh (IMT) tertera pada Tabel 4.

Tabel 4 menunjukan korelasi negatif yang bermakna (derajat sedang $p<0,001$ dan $\mathrm{r}=-0,409$ ), antara umur awitan pubertas dengan IMT. Hal ini berarti semakin tinggi IMT, semakin awal terjadi awitan pubertas. Sedangkan hubungan umur awitan pubertas dengan status ekonomi di kedua daerah mempunyai korelasi positif yang bermakna dengan derajat kuat $\mathrm{r}=0,640$ dan $p<0,001$, semakin tinggi status ekonomi semakin muda awitan pubertas.

Tabel 4. Hubungan umur awitan pubertas dengan status gizi dan status ekonomi

\begin{tabular}{lcc}
\hline Variabel & Koefisien korelasi $(\mathrm{r})$ & $p^{*}$ \\
\hline Indeks massa tubuh & $-0,409$ & $<0,001$ \\
Status ekonomi & 0,640 & $<0,001$ \\
\hline
\end{tabular}

*uji korelasi Spearman

\section{Diskusi}

Awitan pubertas dipengaruhi oleh beberapa sinyal termasuk neurotransmiter dan neuropeptida yang berasal dari hipotalamus yang diteruskan ke perifer dan gonad. Kaprio pada penelitiannya menyimpulkan bahwa variasi usia pubertas melibatkan $74 \%$ faktor genetik dan 26\% faktor lingkungan. Faktor lingkungan meliputi letak geografis, status sosial ekonomi, infeksi, iklim, stresor, dan gangguan pada sistem endokrin yang mempengaruhi jaringan sinyal hipotalamus. ${ }^{2,4}$

Penelitian kami menunjukkan perbedaan status ekonomi antara subjek penelitian di pedesaan dan perkotaan $(p<0,001)$, sesuai dengan data Badan Pusat Statistik pada bulan Maret 2008 bahwa sebagian besar $(63,47 \%)$ penduduk miskin berada di pedesaan. ${ }^{9}$ Perbedaan status ekonomi dan status gizi antara anak perempuan di daerah perkotaan dan pedesaan menyebabkan perbedaan bermakna usia awitan pubertas. Hal yang sama didapatkan oleh Kulin HE $\mathrm{dkk}^{10}$ yang melakukan penelitian di Kenya, bahwa usia awitan pubertas di daerah perkotaan kurang dari 10 tahun, sedangkan di daerah pedesaan $(10,6 \pm 2,4)$ tahun. Status gizi anak yang tinggal di daerah perkotaan di Kenya mempunyai status gizi yang lebih baik. Demikian pula dengan penelitian yang dilakukan

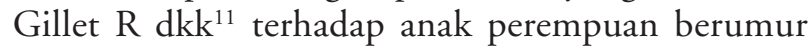
6-18 tahun di Tonga Zambia menyebutkan onset pubertas pada anak perempuan yang ditandai dengan pertumbuhan payudara di perkotaan 11,47 tahun, sedangkan di pedesaan 13,15 tahun.

Pencapaian awitan pubertas yang lebih dini membawa konsekuensi remaja harus menghadapi beberapa permasalahan sehubungan dengan pubertas pada usia yang lebih awal. Permasalahan remaja tersebut di antaranya pubertas yang terlalu cepat atau terlalu lambat, masalah yang berkaitan dengan penampilan fisik, kehamilan dan penyakit seksual, pelecehan seksual, penyalahgunaan obat, gangguan makan, depresi, dan obesitas. ${ }^{12}$

Nilai IMT yang lebih tinggi berhubungan dengan awitan pubertas yang lebih awal. Qing $\mathrm{H}$ dan Karlberg $\mathrm{J}^{13}$ melaporkan bahwa peningkatan 1 unit IMT pada usia antara 2 dan 8 tahun berhubungan dengan peningkatan usia percepatan pertumbuhan saat pubertas $\pm 0,6$ tahun lebih cepat pada anak laki-laki dan 0,7 tahun lebih cepat pada anak perempuan. Kaplowits $\mathrm{P} \mathrm{dkk}^{14}$ melaporkan obesitas merupakan faktor yang berperan penting pada onset pubertas, selain genetik dan lingkungan anak perempuan di Amerika Serikat. Wang $\mathrm{Y}^{15}$ melaporkan anak perempuan dengan IMT $\geq$ persentil 85 dan IMT $\geq$ persentil 90 mengalami pubertas lebih awal. Anak obes mempunyai jaringan lemak yang banyak. Jaringan lemak memproduksi leptin. Kadar leptin dalam darah berhubungan dengan jumlah lemak tubuh dan indeks masa tubuh. Leptin mempunyai peran penting dalam merangsang pubertas dan memelihara aksis hipotalamus-hipofisis-gonad. Leptin dapat bekerja secara langsung maupun tidak langsung pada neuron yang menghasilkan GnRH di hipotalamus dan meningkatkan produksi GnRH, sehingga memulai awitan pubertas melalui sinyal hormonal yang berasal dari jaringan lemak. ${ }^{4}$

Kondisi sosial ekonomi yang cukup berhubungan dengan kemudahan untuk mendapatkan bahan makanan yang berkualitas, di antaranya protein hewani dan lemak jenuh. Makanan sumber protein pada awal kehidupan dapat mempengaruhi waktu pubertas karena rasio yang tinggi antara protein hewani dan nabati pada usia 3-5 tahun berhubungan dengan

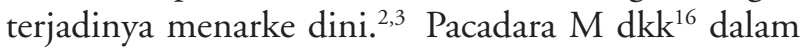
penelitiannya di Kosovo menyebutkan faktor sosial ekonomi menyebabkan asupan makanan yang berbeda secara kualitas dan kuantitas. Anak yang mendapat asupan makanan yang kurang mengalami menarke 13,29 tahun sedangkan yang mendapat asupan makanan yang baik mengalami menarke 12,91 tahun. 
Disimpulkan usia awitan pubertas anak perempuan di daerah perkotaan lebih awal tujuh bulan dibandingkan di daerah pedesaan. Semakin baik status gizi dan semakin tinggi status ekonomi, maka semakin muda usia awitan pubertas anak perempuan. Disarankan perlu penelitian tentang permasalahan pubertas, karena adanya kecenderungan usia pubertas yang lebih dini, anak perempuan harus lebih siap menghadapinya.

\section{Daftar Pustaka}

1. David S, Rosen. Physiologic growth and development during adolescence. Pediatr in Rev 2004; 25:194-9.

2. Parent AN, Teilmann G. The timing of normal puberty and the age limits of sexual precocity: variations around the world, secular trends, and changes after migration. Endoc rev 2003 ; 24:668-87.

3. Schrama K, D Mul. Trend in pubertal development in Europe. Human. Reproduction Update 2001;7:28791.

4. Inserm collective expert report center. Growth and puberty secular trends, environmental and genetic factors. A collective expert report 2007 : 1-24

5. Badan Pusat Statistik RI. Potensi Desa SE 2008. Semarang: BPS; 2008

6. David S, Rosen. Physiologic growth and development during adolescence. Pediatr in Rev 2004;25:194-9.

7. World Health Organization. Training course on child growth assesment Geneva: WHO; 2006.
8. Sajogyo. Pertanian dan kemiskinan. Dalam: Sajogyo, Martowijoyo S, penyunting. Pemberdayaan ekonomi rakyat dalam kancah globalisasi: hasil bahasan seminar pendalaman ekonomi rakyat, Jakarta, Januari-Juli 2002 Bogor: Sajogyo Inside; 2005.h.67-85.

9. Badan Pusat Statistik. Berita resmi Badan Pusat Statistik. Profil kemiskinan di Indonesia, BPS Maret 2008.

10. Kulin HE, Bwibo N, Mutie D, Santner SJ. The effect of chronic childhood malnutrition on pubertal growth and development. Am J Clin Nutr 1982;36: 527-36.

11. Gillet R, Melaoy M, Champbell BC. Catch-up reproductive maturation in rural Tonga girls, Zambia. Am J Hum Biol. 2004;16:658-69. Diunduh pada 17 September 2009 dari http: www.ncbi.nlm.nih.gov/ pubmed/15495232

12. Gentry JH, Campbell M. Developing adolescents : a reference for professionals. Am Phychol Ass 2002; $1-33$.

13. Qing H, Karlberg J. Body mass index in childhood and its association with height gain, timing of puberty, and final height. Pediatr Research. 2001;49: 241-53.

14. Kaplowitz P, Slora EJ, Wasserman RC, Pedlow SE. Early onset of puberty in girls: relation to increased body mass index and race. Pediatrics 2001;108:347- 53.

15. Wang Y. Is obesity associated with early sexual maturation? A comparison of the association in American boys versus girls. Pediatrics 2002;110:903-10.

16. Pacarada M, Lulaj S, Kongjeli G, Obertinca B. Impact of socio-economic factors on the onset of menarche in Kosovar girls. J Chin Clin Med 2008;3:541-9. 